\title{
Mirosława Mycawka, Język polski XIV wieku. Wybrane zagadnienia, Wydawnictwo Uniwersytetu Jagiellońskiego, Kraków 2012, ss. 201
}

Pod koniec 2012 roku ukazała się książka ważna - jedna z tych, które w obszarze historii języka ukazują się nie częściej niż co kilka lat. Jest to monografia Mirosławy Mycawki Język polski XIV wieku. Wybrane zagadnienia. O jej wartości stanowią moim zdaniem przede wszystkim następujące względy i okoliczności.

1. Wybór tematu. Postępując śladami Baudouina de Courtenay ( $O$ drevnopol'skom jazyke do XIV-go stoletija, 1870), po stu latach od ukazania się jego dzieła Bogusław Dunaj przedstawił odpowiadające współczesnym standardom metodologicznym opracowanie pierwszych wieków doby piśmiennej języka polskiego - Język polski najstarszej doby piśmiennej: XII-XIII w. (1975). Monografia oparta jest w całości na materiale polskich nazw własnych i wyjątkowych wyrazów apelatywnych pojawiających się w dokumentach łacińskich. Jak doskonale wiadomo historykom języka, wiek XIV zajmuje pośrednie miejsce między wiekami ,,polszczyzny dyplomowej” a okresem, z którego dysponujemy nieprzerwanym już szeregiem polskich tekstów ciągłych. Zaczyna się ten szereg od najstarszych rot sądowych i Psalterza floriańskiego, czyli od ostatnich lat XIV stulecia. Wcześniejsze, ale wyjątkowo kontrowersyjne co do datowania, są właściwie tylko dwa teksty: najstarsza część Bogurodzicy i $\mathrm{Ka}$ zania świętokrzyskie. Jeśli je wyłączyć, dla XIV wieku mamy, jak dla dwu wieków poprzednich, materiał onimiczny i bardzo skąpy apelatywny w postaci zanotowanych w dokumentach łacińskich (rzadziej niemieckich) nazw własnych i nielicznych wyrazów pospolitych, głównie nazw powinności feudalnych, oraz nieliczne i bardzo krótkie teksty ciągłe w rodzaju pieśni wielkanocnej Krystus z martwych wstat je. Dopiero w ostatnich latach stulecia pojawiają się, jak wspomniałem wyżej, najstarsze roty sądowe i pierwsza część Psałterza 
floriańskiego. I roty, i Psatterz doczekały się gruntownego monograficznego opisu (w pracach Marii Trawińskiej, Sylwii Przęczek-Kisielak, Marii Kamińskiej i Marka Cybulskiego). W tej sytuacji praca Mirosławy Mycawki, wiążąca w planie chronologicznym swoimi ustaleniami wyniki monografii Bogusława Dunaja z wynikami prac wyżej wspomnianych badaczy rot i Psalterza floriańskiego, wypełnia dotkliwą lukę w literaturze historycznojęzykowej.

2. Samoistna wartość naukowa i dydaktyczna części wstępnej (s. 9-49). Autorka w sposób wzorowy (zwięzły, zdyscyplinowany, głęboko przemyślany, gruntownie sproblematyzowany i atrakcyjnie sformułowany) omówiła tu (krytycznie, polemizując z niektórymi tezami i ustaleniami innych uczonych, ale zarazem dając przykład wielkiej kultury polemicznej) wiele fundamentalnych kwestii teoretyczno-metodologicznych językoznawstwa diachronicznego w ogólności, a historii języka polskiego, w tym też dialektologii historycznej, w szczególności. Przedstawiła źródła do dziejów polszczyzny XIV wieku, stan badań nad tym okresem jej historii (słusznie podkreślając dotychczasowy brak zainteresowania materiałem „dyplomowym”), oceniła poziom edytorski kanonu źródeł, scharakteryzowała metody badawcze językoznawstwa diachronicznego na tle zmieniających się paradygmatów badawczych lingwistyki (młodogramatycznego, strukturalistycznego, komunikologicznego i kognitywistycznego) itd. Jak najbardziej zasadnie więcej miejsca i uwagi poświęciła takim problemom teoretyczno-warsztatowym jak relacja między grafią a wymową, interpretacja procesów historycznojęzykowych (dyferencjacji i integracji, w tym genezy polskiego języka literackiego), dialektologia historyczna (jej istota, przedmiot i metody) itd. Zakończyła te uwagi wstępne zwięzłą charakterystyką najważniejszych procesów językowych w dziejach polszczyzny przed wiekiem XIV. Ta część pracy Mirosławy Mycawki winna stać się obowiązkową lekturą wszystkich uczestników językoznawczych seminariów magisterskich i doktoranckich wybierających jako obszar swych badań językoznawstwo diachroniczne.

3. Bogactwo materiałowe monografii. Jest ono konsekwencją wyzyskania bardzo obszernego kanonu źródeł. Jak stwierdza autorka: „Dokumentacja przykładowa pochodzi z ponad dwóch tysięcy dokumentów" (s. 14). Tylko doświadczony historyk języka jest w pełni świadom tego, że za tą subiektywną deklaracją kryje się ogrom mrówczej, benedyktyńskiej pracy, wymagającej najwyższych kwalifikacji i kompetencji filologicznych.

4. Zalety warsztatu naukowego autorki. Odznacza się on wieloma pożądanymi cechami, wśród których na szczególne podkreślenie zasługują dwie: bardzo wysoki stopień filologicznej akrybii oraz ostrożność w wyciąganiu wniosków i formułowaniu tez. Akrybia owocuje precyzją analizy i uzasadnioną nieufnością wobec izolowanych wyjątkowych zapisów. Warto tu przytoczyć 
następującą deklarację autorki: „Analiza materiału wydobytego z dokumentów łacińskich jest narażona na niebezpieczeństwo atomistycznego podejścia, tzn. traktowania przykładów w izolacji. By tego uniknąć, zastosowałam dwustopniowy sposób gromadzenia materiału. Najpierw rozpisywałam dokumentację źródłową z danego dokumentu w całości, co w późniejszej analizie umożliwiało szybką weryfikację konwencji ortograficznych i wykrycie ewentualnych substytucji niemieckich, następnie wydobywałam z tych wyciągów przykłady ilustrujące poszczególne zagadnienia. Metoda taka jest bardziej czasochłonna, ale zapewnia ona wiarygodniejsze rezultaty badawcze ze względu na możliwość analizy zapisów na szerszym tle" (s. 14). Wiarygodność wyników rozprawy jest też pochodną ostrożności badaczki: nigdy nie formułuje ona tez i twierdzeń w sposób apodyktyczny, wykluczający dyskusję. Przeciwnie: każdą tezę obwarowuje różnymi, czasem licznymi, zastrzeżeniami. W odniesieniu do tak złożonej i subtelnej materii, jaką jest ewolucja języka, na którą ma wpływ wiele najrozmaitszych czynników, jest to postawa najwłaściwsza, godna uznania i zalecenia.

Jestem głęboko przekonany, że dzięki wyżej wskazanym zaletom monografia Mirosławy Mycawki znajdzie poczesne miejsce w trwałym dorobku językoznawstwa polonistycznego. 